\section{Avaliação in vivo e in vitro da sensibilidade do $P$. falciparum a quinino e mefloquina em área endêmica de malária na Amazônia brasileira (Peix oto de Azevedo, Estado do Mato Grosso)}

Para o controle da malária, são indispensáveis o diagnóstico precoce e o tratamento eficaz. A eficácia dos antimaláricos deve ser constantemente monitorizada, preferencialmente por testes in vivo e in vitro. No presente trabalho, após revisão dos mecanismos de resistência do $P$. falciparum às drogas antimaláricas, dos métodos disponíveis para a avaliação desta resistência, de sua disseminação e dinâmica, e das perspectivas de desenvolvimento de novos fármacos, são apresentados os resultados de avaliação da sensibilidade do parasita a quinino e mefloquina no município de Peixoto de Azevedo, MT, área endêmica da região Amazônica brasileira. Os pacientes foram internados em enfermaria, em local livre de transmissão, durante 14 a 28 dias, de forma a evitar reinfecção durante o período de acompanhamento. Noventa e seis pacientes foram acompanhados após tratamento com mefloquina (1 $\mathrm{g} \mathrm{VO}$ em dose única). Houve duas falhas terapêuticas (RI e RII), com eficácia de $97,9 \%(92,6 \%$ a $99,6 \%)$ ou, considerando a pior eficácia, 95,8\% (89,6\% a 98,8\%). Tempos de clareamento parasitário pela gota espessa e pelo QBC® foram, em média $45,7 \mathrm{~h}( \pm 11,4)$ e $54,9 \mathrm{~h}( \pm 17,9)$, respectivamente. Trinta e três pacientes foram acompanhados durante e após tratamento com quinino $(500 \mathrm{mg} \mathrm{VO} 8 / 8 \mathrm{~h}$ durante dez dias), não havendo falhas terapêuticas. $A$ eficácia foi de $100 \%(87,01 \%$ a $100 \%)$ ou, considerando a pior eficácia, $97 \%(82,4 \%$ a $99,8 \%$ ). Tempos de clareamento parasitário pela gota espessa e pelo QBC $\AA$ foram, em média $58,8 \mathrm{~h}( \pm 3,6)$ e $77,6 \mathrm{~h}( \pm 4,5)$, respectivamente. Foram realizados 114 microtestes de sensibilidade de Rieckmann et al, dos quais 49 forneceram resultados válidos. Foi observada resistência à cloroquina em $95,6 \%$ dos isolados avaliados

\section{In vivo and in vitro evaluation of $P$. falciparum sensitivity to quinine and mefloquine in an endemic area of the Brazilian Amazon Region (Peix oto de Azevedo, Mato Grosso State)}

Early diagnosis and effective treatment are essential tools for malaria control. The efficacy of antimalarial drugs should be monitored frequently, preferentially by in vivo and in vitro methods. This study reviews the mechanisms of Plasmodium falciparum resistance to antimalarial drugs, the methods for its evaluation, its dissemination and dynamics, and the perspectives for the development of new drugs. It also presents data about Plasmodium falciparum sensitivity to quinine and mefloquine obtained in an evaluation carried out in Peixoto de Azevedo Municipality (MT), an endemic area of the Brazilian Amazon Region. The patients were admitted to a ward for 14 to 28 days, in order to avoid reinfection in the follow-up period. The ward was located in a place without malaria transmission. Ninety-six patients were followed after treatment with mefloquine (1 $\mathrm{g}$ PO single dose). There were two therapeutic failures (RI and RII), giving $97.9 \%$ efficacy $(92.6 \%$ to $99.6 \%)$ or, if one considers the worst possible efficacy, $95.8 \%(89.6 \%$ to 98.8\%). Parasite clearance times by thick smears and by QBC( were on average $45.7 \mathrm{hr}$. $( \pm 11.4)$ and $54.9 \mathrm{hr}$. ( \pm 17.9$)$, respectively. Thirtythree patients were followed during and after treatment with quinine $500 \mathrm{mg} P O$ every 8 hours for ten days), with no therapeutic failures. The efficacy was $100 \%(87.01 \%$ to $100 \%)$ or, if one considers the worst possible efficacy, $97 \%$ (82.4\% to $99.8 \%)$. Parasite clearance times by thick smears and by QBC® were on average $58.8 \mathrm{hr} .( \pm 3.6)$ and $77.6 \mathrm{hr}$. ( \pm 4.5$)$, respectively. One hundred and fourteen Rieckmann sensitivity microtests were performed and 49 of them could be analyzed. In vitro chloroquine resistance was observed in $95.6 \%$ of the tested isolates (43/45). Regarding quinine, $10.6 \%$ of the tested isolates showed resistance or low

Recebido para publicação em 21/5/98. 
(43/45). Em relação ao quinino, 10,6\% dos isolados avaliados apresentaram resistência ou baixa sensibilidade (4/38). Em relação à mefloquina, $52,4 \%$ dos isolados testados foram inibidos por baixas concentrações da droga (22/42). Foram determinadas as concentrações inibitórias para $50 \%, 90 \%$ e $99 \%$ dos parasitas (Cl 50, $\mathrm{Cl} 90$ e Cl 99). Para a cloroquina, foram observadas: $\mathrm{Cl} 50=1,47 \mu \mathrm{mol} / \mathrm{I}, \mathrm{Cl} 90=$ $21,19 \mu \mathrm{mol} / \mathrm{l}$ e Cl $99=186,1 \mu \mathrm{mol} / \mathrm{l}$. Para o quinino: $\mathrm{Cl} 50=1,13 \mu \mathrm{mol} / \mathrm{l}, \mathrm{Cl} 90=8,18 \mu \mathrm{mol} / \mathrm{l} \mathrm{e} \mathrm{Cl} 99=$ $41,11 \mu \mathrm{mol} / \mathrm{l}$. Para a mefloquina: $\mathrm{Cl} 50=$ $0,24 \mu \mathrm{mol} / \mathrm{l}, \mathrm{Cl} 90=3,75 \mu \mathrm{mol} / \mathrm{l}$ e Cl $99=$ $34,9 \mu \mathrm{mol} / \mathrm{l}$. Não houve correlação entre as concentrações inibitórias in vitro e os tempos de clareamento parasitário in vivo. Estes resultados demonstram considerável eficácia in vivo do quinino e da mefloquina nesta região da bacia Amazônica. sensitivity (4/38). As for mefloquine, $52.4 \%$ of the tested isolates were inhibited by low concentrations of the drug (22/42). Inhibitory concentrations for $50 \%, 90 \%$ and $99 \%$ of the parasites were determined (IC 50, IC 90 and IC 99), with the following results: chloroquine IC 50 $=1.47 \mu \mathrm{mol} / \mathrm{I}, \mathrm{IC} 90=21.19 \mu \mathrm{mol} / \mathrm{I}$ and $\mathrm{IC} 99=$ $186.1 \mu \mathrm{mol} / /$; quinine IC $50=1.13 \mu \mathrm{mol} / \mathrm{l}$, IC $90=$ $8.18 \mu \mathrm{mol} / \mathrm{l}$ and $\mathrm{IC} 99=41.11 \mu \mathrm{mol} / \mathrm{l}$; mefloquine IC $50=0.24 \mu \mathrm{mol} / \mathrm{I}, \mathrm{IC} 90=3.75 \mu \mathrm{mol} / \mathrm{I}$ and IC 99 $=34.9 \mu \mathrm{mol} / \mathrm{l}$. There was no correlation between in vitro inhibitory concentrations and in vivo parasite clearance times. These results indicate a considerable in vivo efficacy of quinine and mefloquine in this region of the Amazon Basin.

Crispim Cerutti Junior

Dissertação apresentada à Faculdade de Medicina da Universidade de São Paulo para obtenção do Título de Mestre

São Paulo, SP, Brasil, 1998. 